\title{
Rootstock influences on photosynthetic performance of young 'Interdonato' trees grown in calcareous soil
}

\author{
Berken ÇIMEN $\mathbb{D}_{1}$
}

${ }^{1}$ Cukurova University, Faculty of Agriculture, Department of Horticulture, Adana

Alınıs tarihi: 8 Mayıs 2019, Kabul tarihi: 19 Temmuz 2019

Sorumlu yazar: Berken ÇiMEN, e-posta: bcimen@cu.edu.tr

\begin{abstract}
Tree nutrient imbalances stimulated by iron (Fe) deficiency in calcareous soils often affect citrus trees grown in the Mediterranean basin. Rootstock choice can help with nutritional imbalances along with abiotic management issues. The present study evaluated the growth and photosynthetic performances of young 'Interdonato' trees grafted on 'Alemow', 'Bitters', 'Carpenter', Carrizo', 'Furr', 'sour orange', 'US812', 'Volkameriana' and 'X639' grown in calcareous soils in Mediterranean region of Turkey. Plant growth of the scion budded on Alemow, sour orange and Volkameriana was significantly higher than those grafted on other rootstocks. Bitters produced significantly smaller trees than Alemow, sour orange and Volkameriana. In addition, scion grafted on sour orange (0.99) had the highest compatibility. Rootstocks affected leaf chlorophyll concentration and PSII efficiency. Leaves of 'Interdonato' budded on Carrizo citrange displayed a significant decrease in photosynthetic rate $\left(P_{\mathrm{N}}\right)$, stomatal conductance and PSII efficiency when compared to other rootstocks evaluated in this study. Young Interdonato trees budded on to Bitters rootstock had significantly higher $P_{\mathrm{N}}$ in comparison to Carpenter, Furr and Carrizo citrange in calcareous soil.
\end{abstract}

Key words: Citrus, chlorophyll concentration, net photosynthetic rate, chlorophyll fluorescence

\section{Anaçların kireçli topraklarda yetişen genç 'Interdonato' ağaçlarının fotosentetik performanslarına etkileri}

Öz

$\mathrm{Bu}$ çalışmada Akdeniz havzasının kireçli topraklarında yetiştirilen 'Alemow', 'Bitters', 'Carpenter', Carrizo', 'Furr', yerli turunç, 'US812', 'Volkameriana' ve 'X639' anaçları üzerine aşllı genç 'Interdonato' limon ağaçlarının büyüme ve fotosentetik performansları değerlendirilmiștir. Alemow, Volkameriana ve yerli turunç anaçları üzerine aşılı ağaçların bitki gelişimi diğer anaçlara kıyasla daha yüksek olduğu belirlenmiştir. Bitters anacı üzerine aşılı ağaçların ise Alemow, yerli turunç ve Volkameriana anaçları üzerine aşlı olanlardan daha küçük taç oluşturduğu gözlemlenmiştir. Ayrıca, en iyi aşı uyuşma oranının yerli turunç anacı (0.99) üzerine aşılı limon ağaçlarında olduğu belirlenmiştir. Anaç kullanımı yaprak klorofil konsantrasyonunu ve klorofil ışıma verimliliğini etkilemiştir. Çalışmada değerlendirilen diğer anaçlarla kıyaslandığında, Carrizo sitranjı üzerine aşılı olan limon bitkilerinin yapraklarinda fotosentez hizı $\left(P_{\mathrm{N}}\right)$, stomatal iletkenlik ve klorofil ışıma verimliliği değerlerinde önemli ölçüde azalmalar olduğu saptanmıştır. Kireçli topraklarda yetiştirilen Bitters anacı üzerine aşılı bitkilerin fotosentez hizlarının Carpenter, Furr ve Carrizo anaçları üzerine aşılı olanlardan daha yüksek olduğu belirlenmiştir.

Anahtar kelimeler: Turunçgil, klorofil konsantrasyonu, net fotosentez oranı, klorofil ışıma verimliliği 


\section{Introduction}

Turkey's citrus-producing regions are located in the northern half of the world's citrus-producing region, and Turkey has exceptionally reasonable environmental conditions and citrus-producing prospective, with $4,769,726$ tons of citrus fruit produced in 2017 (FAO 2019). Turkey's lemon production has expanded considerably over the years, approaching approximately one million tons in 2017. Lemon production in Turkey is very important in terms of its large export volume. Turkey produced 850.600 tons of lemons in 2016 and exported 448.781 tons of this production amount in the identical year (FAO, 2019). Turkey is the leading producer and exporter of the 'Interdonato' lemon variety in the world and approximately $2 / 3$ of our lemon export is this variety. 'Interdonato ' is considered a lemon-citron hybrid, which originated on Colonel Interdonato's property in Nice, Sicily, around 1875. It has good resistance to mal secco and therefore Turkish farmers prefer this variety. Interdonato variety has a medium to large fruit size, with an oval shape; the epicarp is smooth and thin with expanded oil glands. The juice, of yield of $25 \%$ or more and total acidity less than $5 \%$, is rich in specific substances, such as vitamin $\mathrm{C}$, which takes a part in numerous metabolic activities of the human body (Salvo et al., 2016).

As mentioned above, citrus is the main fruit group growing in the Mediterranean region of Turkey where the fruit trees can suffer from iron deficiency. Fe deficiency is a common issue in fruit trees grown in the Mediterranean region due to high calcareous soils. Lime induced Fe chlorosis negatively affects many of the plants grown in this area with its high humidity and semi-humid climate. In this region including our country, $20-50 \%$ of the fruit trees face lime induced $\mathrm{Fe}$ chlorosis. The Mediterranean basin often has soils that have more than $20 \%$ of calcium and magnesium carbonates and where $\mathrm{pH}$ ranges between 7.5 and $8.5 \mathrm{Fe}$ uptake depends heavily upon the $\mathrm{pH}$ of the land and solution of iron reduces by 1,000 folds for each $\mathrm{pH}$ uptake in a range from 7.4 to 8.5. Citrus, grapes, kiwifruit, raspberry and pineapple are fruit crops the most affected by $\mathrm{Fe}$ chlorosis (Byrne et al., 1995; González-Vallejo et al., 2000; López-Millán et al., 2000; Pestana et al., 2005; Fernández et al., 2006).

Rootstocks have an extremely significant part in citriculture. Rootstock selection in citrus production has an important place in profitable production with preventive factors such as climate, bad soil situations, diseases etc. In order to increase quality and production in fruit crops, early fruit production, consistent crop production, short juvenility period, the control of tree size, and planting high density etc., growers have a wide variety of options to use citrus rootstocks. The choice is an imperative decision and ecological conditions are important factors in the selection of the rootstock. In spite of the fact that a large number of citrus genotypes can be utilized as a rootstock, a few of them are superior and more suited to particular conditions than others (Yildirim et al., 2010; Cimen and Yesiloglu, 2016). There is, however, no ideal rootstock for all horticultural benefits and abiotic and biotic stress conditions. For instance, sour orange (Citrus aurantium L.) is tolerant to root rot, calcareous soils, drought, and cold, and producing high yield and high fruit quality. In contrast, it is susceptible to citrus tristeza virus (CTV). In some countries, the use of this rootstock is declining due to the presence of CTV. On the contrary, Volkamer lemon, rough lemon, and Rangpur lime positively affect fruit yield. However, they reduce fruit quality as compared to fruits obtained from trifoliate orange, Carrizo and Troyer citranges, which show sensitive characteristics to cold weather (Cimen and Yesiloglu, 2016).

Rootstocks positively affect scion growth, fruit internal/external quality and fruit yield (FornerGiner et al., 2003; Castle et al., 2009), along with photosynthesis (González-Mas et al., 2009). Amongst other physiological progressions, photosynthesis $\left(P_{\mathrm{N}}\right)$ is one of the elementary factor of plant productivity and the ability to preserve the percentage of carbon assimilation under ecological stress (Lawlor, 1995).

In the present study, leaf chlorophyll concentration (Chl), chlorophyll fluorescence and gas exchange measurements have been assessed in this regard by the impact of several citrus rootstocks on the photosynthetic performance of the Interdonato lemon variety grown under calcareous soil.

\section{Material and Methods}

\section{Plant material and growth conditions}

The current study was established in citrus fields (Latitude, 36 $54^{\circ} 8.35^{\prime \prime} \mathrm{N}$; Longitude, 35³3'4.07"E; Altitude $11 \mathrm{~m}$ ) of Atlas Tarim in Adana province of Turkey. Two years old 'Interdonato' lemon trees grafted on to 'Alemow', 'Bitters', 'Carpenter', Carrizo', 'Furr', 'sour orange', 'US812', 'Volkameriana' and 
'X639' rootstocks. Bitters, Carpenter and Furr are new rootstocks derived by crosses of Sunki mandarin $\mathrm{x}$ Swingle trifoliate orange originally produced by a rootstock-breeding program in the USA. Each produces uniform seedlings due to its high nucellar embryony and they are compatible with Lisbon lemon. In addition, Bitters is very tolerant of calcareous soil (Federici et al., 2009). US812 is the result of a cross (Sunki mandarin $x$ Benecke trifoliate) which is highly productive of good quality fruit. The US812 has tolerance or resistance to CTV and citrus blight (Bowman and Rouse, 2006). X639 is a hybrid of Cleopatra mandarin and Poncirus trifoliata. In most features, trees on X639 are similar in quality, tree form and yield, such as Troyer, but growth is slightly slower (UCR 2019).

Polyembriyonic seeds of 'Alemow', 'Bitters', 'Carpenter', Carrizo', 'Furr', 'sour orange', 'US812', 'Volkameriana' and 'X639' were sowed in the dark at $24^{\circ} \mathrm{C}$ in plates with $1: 1$ peat:soil growing medium. Then uniform seedlings were transported into the soil in pots for grafting of scion. Budwoods of 'Interdonato' lemon variety were grafted on approximately one-year old seedlings. Young trees were planted in the orchard 8 months after grafting. When trees were two years old, chlorophyll concentration, fluorescence and gas exchange measurements were recorded from fully expanded young 'Interdonato' leaves on each rootstock, arranged in a 'complete randomized' experimental plot. The soil was a clay-loam and the $\mathrm{pH}$ of the soil was considered alkaline in the experimental area from 7.8 to 8.1 at a depth of $0-90 \mathrm{~cm}$. The trees were irrigated weekly from May to October using drip irrigation.

Rootstock and scion diameters were used as plant growth indicators in the present study. Rootstock and scion diameters were measured $5 \mathrm{~cm}$ below and above the bud union, respectively by a digital caliper (Mitutoyo CD-15CPX). The compatibility was calculated as the ratio of 'scion diameter/stock diameter' by using data from diameter measurements.

\section{Gas exchange measurements}

A portable photosynthesis system detected the leaf gas exchange parameters of fully developed 4 th to 5 th leaves from the shooting apex (model LCA-4, ADC Bioscientific Ltd., Hoddesdon, UK) per each rootstocks (Cimen et al., 2014). Portable photosynthesis system measured net photosynthetic rate, $P_{\mathrm{N}}\left[\mu \mathrm{mol}\left(\mathrm{CO}_{2}\right) \mathrm{m}^{-2} \mathrm{~s}^{-1}\right]$; transpiration rate, $E$ (mmol m $\left.\mathrm{m}^{-2} \mathrm{~s}^{-1}\right)$; stomatal conductance, $g_{\mathrm{s}}\left(\mathrm{mmol} \mathrm{m} \mathrm{m}^{-2} \mathrm{~s}^{-1}\right)$; stomatal resistance $\left(\mathrm{m}^{2} \mathrm{~s} \mathrm{~mol}^{-1}\right)$; and intercellular $\mathrm{CO}_{2}$ concentration, $C_{\mathrm{i}}$ [ $\mu \mathrm{mol}\left(\mathrm{CO}_{2}\right) \mathrm{mol}^{-1}$ (air)] in each single measurement. The instantaneous photosynthetic water use efficiency was predicted as 'WUE $=P_{\mathrm{N}} / \mathrm{E}^{\prime}$ according to Ribeiro et al. (2009). During the gas exchange measurements, leaf temperature ranged between 25 and $28^{\circ} \mathrm{C}$ and the relative humidity was $60 \%$ where PFD was detected as $850-900 \mu \mathrm{mol} \mathrm{m}^{-2} \mathrm{~s}^{-1}$.

\section{Leaf chlorophyll concentration and Photosystem II efficiency}

For the estimation of leaf Chl concentrations by SPAD-502 chlorophyll meter, the same leaves were used with the measures for gas exchange (Minolta Inc., Osaka, Japan). Because SPAD reading and chlorophyll levels in citrus leaves are strongly linked, SPAD readings were used to estimate the concentration of Chl leaves (Jifon et al., 2005). Also, PSII maximum efficiency $\left(F v^{\prime} / F m^{\prime}\right)$, minimum fluorescence $\left(F_{0}{ }^{\prime}\right)$ and variable fluorescence $\left(F v^{\prime}\right)$ readings in a light-adapted leaf phase were measured at the same leaves by using a portable fluorimeter (FluorPen FP100, Photon System Instruments Ltd, Drasov, Czech Republic).

\section{Statistical analysis}

The experiment was organized as $9 \times 6$, nine rootstocks, six replicates, respectively, in a 'Randomized Block Design'. The data were tested by an analysis of variance (ANOVA). The means and calculated standard deviations were stated. Least significant difference (LSD) test was used for mean comparison within rootstocks when the $F$ test was significant at $P<0.05$. The 'Correlation coefficients' were also calculated between all measured parameters. Data subjected to ANOVA by the SAS v9 statistical analyses software and SigmaPlot $\AA$ v11 (Systat Software, San Jose, CA, USA) was used for data presentation.

\section{Results and Discussion \\ Plant Growth}

Stock diameter significantly differed $(P \leq 0.01)$ among rootstocks according to a one-way ANOVA (Table 1). During the experiment, maximum stock diameter development was observed in Volkameriana (41.82 $\mathrm{mm}$ ) followed by Alemow (33.66 $\mathrm{mm}$ ). The diameter development was $24.94 \mathrm{~mm}$ and $23.91 \mathrm{~mm}$ in Bitters and Furr rootstocks, respectively. The lowest diameter development was recorded in US812 rootstock (21.04 $\mathrm{mm})$. 
Table 1. Stock and scion diameter ( $\mathrm{mm}$ ) and compatibility (scion/stock ratio) of 'Interdonato' lemon variety grafted on different rootstocks grown in calcareous soils

\begin{tabular}{cccc}
\hline Rootstock & Stock diameter & Scion diameter & Scion/Stock ratio \\
\hline Alemow & $33.66 \pm 1.26^{\mathrm{b}} \mathrm{b}$ & $31.23 \pm 1.33^{\mathrm{b}}$ & $0.93 \pm 0.01^{\mathrm{bc}}$ \\
Bitters & $24.94 \pm 2.58^{\mathrm{d}}$ & $22.59 \pm 2.15^{\mathrm{de}}$ & $0.90 \pm 0.04^{\mathrm{bcd}}$ \\
Carpenter & $25.25 \pm 1.47^{\mathrm{cd}}$ & $22.04 \pm 1.18^{\mathrm{e}}$ & $0.76 \pm 0.02^{\mathrm{d}}$ \\
Carrizo citrange & $22.79 \pm 2.25^{\mathrm{de}}$ & $20.92 \pm 2.40^{\mathrm{ef}}$ & $0.92 \pm 0.06^{\mathrm{bc}}$ \\
Furr & $23.91 \pm 1.18^{\mathrm{d}}$ & $21.34 \pm 2.01^{\mathrm{ef}}$ & $0.89 \pm 0.07^{\mathrm{cd}}$ \\
Sour orange & $27.79 \pm 1.80^{\mathrm{c}}$ & $27.64 \pm 1.80^{\mathrm{c}}$ & $0.99 \pm 0.01^{\mathrm{a}}$ \\
US812 & $21.04 \pm 1.24^{\mathrm{e}}$ & $19.15 \pm 1.22^{\mathrm{f}}$ & $0.91 \pm 0.01^{\mathrm{bcd}}$ \\
Volkameriana & $41.82 \pm 2.60^{\mathrm{a}}$ & $39.58 \pm 2.52^{\mathrm{a}}$ & $0.94 \pm 0.02^{\mathrm{b}}$ \\
X639 & $27.66 \pm 1.48^{\mathrm{c}}$ & $24.96 \pm 1.21^{\mathrm{cd}}$ & $0.90 \pm 0.03^{\mathrm{bcd}}$ \\
\hline Prob>F & $<.0001$ & $<.0001$ & 0.0011 \\
LSD\%5 & 2.675 & 2.853 & 0.045 \\
\hline
\end{tabular}

${ }^{1}$ For each variable, one-way analysis of variance was performed with rootstocks as the independent variable. Values in rows followed by the different letters are statistically different at $\mathrm{P}<0.05$ (LSD test).

Statistical ANOVA showed that different rootstocks significantly affected $(P \leq 0.01)$ scion diameter $(\mathrm{mm})$ of young 'Interdonato' lemon trees (Table 1). 'Interdonato' lemon grafted on Volkameriana had the highest diameter with $39.58 \mathrm{~mm}$ followed by Alemow $(31.23 \mathrm{~mm})$. There were no significant differences with Furr and Carrizo citrange in terms of their effect on scion diameter in 'Interdonato' lemon variety. The lowest scion diameter was from trees grafted on to US812 rootstock $(19.15 \mathrm{~mm})$. High pH (Yang et al., 2008) and bicarbonate ions in calcareous soils (Pestana et al., 2005; Cimen et al., 2014) reduce plant development. Shah et al. (2016) established that Meyer lemon when grafted on sour orange rootstock affected scion diameter and scion length. However, Legua et al. (2011) reported no statistical differences for tree height, canopy diameter and canopy volume among four citrus rootstocks on 'Lane Late' navel orange. Also in a study on 'Navelina' orange, researchers found similar tree height and canopy volume on $C$. volkameriana and Cleopatra mandarin (Forner-Giner et al., 2003). In contrast, Cleopatra mandarin had lower tree height when it was compared with 'Carrizo' and 'Swingle' rootstocks in a study on 'Marisol' Clementine mandarin (Bassal, 2009).

The ratio between scion and rootstock diameter is a useful an indicator of the scion/rootstock compatibility and the ratio those are close to ' 1 ' are associated with very good compatibility (Bisio et al., 2003; Bassal, 2009). The highest compatibility for lemon was associated with sour orange (0.94). There were no significant differences with Bitters (0.90), US812 (0.91) and X639 (0.90). The lowest compatibility was determined in young lemon trees grafted on to Carpenter rootstock $(0.76)$ grown in calcareous soils (Table 1 ).

\section{Chlorophyll concentration and PSII efficiency}

In the present study, as a result of the positive linear relationship $\left(r^{2}>0.8\right)$ between SPAD readings and Chl leaf concentrations, SPAD measurements were used to predict leaf levels of Chl (Jifon et al., 2005). Compared to all other rootstocks, calcareous soil caused a remarkable decrease of leaf Chl content in 'Interdonato' grafted on 'Carrizo' citrange (Table 2). In contrast, the highest leaf $\mathrm{Chl}$ content was estimated in the leaves on Alemow (51.01), followed by sour orange (49.41), Volkameriana (49.05) and Bitters (48.17). The concentration of $\mathrm{Chl}$ was not significantly differed in the leaves of 'Interdonato' lemon on sour orange, Volkameriana and Bitters growing in calcareous soil. The present study indicated that the Bitters rootstock showed good tolerance to lime-induced $\mathrm{Fe}$ chlorosis as much as sour orange. $\mathrm{Fe}$ is especially important in the synthesis and stabilisation of chlorophyll (Pestana et al., 2011). A number of authors have classified Fe tolerance to citrus rootstocks based on shoot and leaf chlorosis parameters. In deprived Fe conditions, sour oranges kept their content significantly higher than trifoliate orange and hybrids, compared to chlorophyll. (Byrne et al., 1995; Castle et al., 2009; Cimen et al., 2014).

Leaves of 'Interdonato' lemon grafted on to sour orange had significantly $(P \leq 0.05)$ higher minimum fluorescence $\left(F_{0}\right)$ than those on the other rootstocks in calcareous soil. On the other hand, $F_{0}{ }^{\prime}$ was the lowest in leaves of scion grafted on to Carrizo citrange. Variable fluorescence $\left(F v^{\prime}\right)$ of leaves of 'Interdonato' lemon variety was not affected by 
rootstocks significantly. $F V^{\prime}$ ranged between 1715.25 and 1790.50 (Table 2). Scion PSII efficiency was affected significantly by rootstocks $(P \leq 0.05)$. There have been slight decreases in shot leaves on all the rootstocks evaluated in this study, except Alemow (Table 2). PSII efficiency in the leaves of shoots grafted on Alemow, sour orange and Volkameriana were recorded slightly higher than those on others. The declines in chlorophyll fluorescence variables from Navelina grafted on Carrizo rootstock in calcareous soil have been reported by Gonzáles-Mas et al. (2009). In addition, Pestana et al. (2011) indicated that chlorophyll fluorescence of Newhall navel grafted on Troyer rootstock decreased under iron deficiency. In the present study, PSII activity, in the light adapted period of the leaves, slightly reduced in all rootstocks except Alemow, sour orange, and Volkameriana grown in calcareous soil.

Table 2. Leaf chlorophyll ( $\mathrm{Chl}$ ) concentration (SPAD readings) and chlorophyll fluorescence variables of 'Interdonato' lemon variety grafted on different rootstocks grown in calcareous soils

\begin{tabular}{ccccc}
\hline Rootstock & Chl & $F 0^{\prime}$ & $F V^{\prime}$ & PSII \\
\hline Alemow & $51,01 \pm 3.12^{\mathrm{a}}$ & $384.75 \pm 5.38^{\mathrm{ab}}$ & $1790.50 \pm 4.80$ & $0.7112 \pm 0.08^{\mathrm{a}}$ \\
Bitters & $48,17 \pm 5.66^{\mathrm{ab}}$ & $287.75 \pm 7.76^{\mathrm{c}}$ & $1736.00 \pm 2.58$ & $0.6410 \pm 0.02^{\mathrm{b}}$ \\
Carpenter & $43,57 \pm 4.26^{\mathrm{cde}}$ & $253.00 \pm 3.92^{\mathrm{d}}$ & $1715.25 \pm 5.06$ & $0.6134 \pm 0.06^{\mathrm{b}}$ \\
Carrizo citrange & $42.35 \pm 5.94^{\mathrm{e}}$ & $215.00 \pm 6.78^{\mathrm{e}}$ & $1718.75 \pm 2.22$ & $0.6127 \pm 0.07^{\mathrm{b}}$ \\
Furr & $42.54 \pm 3.21^{\mathrm{de}}$ & $271.75 \pm 6.40^{\mathrm{cd}}$ & $1721.75 \pm 2.99$ & $0.6212 \pm 0.02^{\mathrm{b}}$ \\
Sour orange & $49.41 \pm 4.39^{\mathrm{ab}}$ & $395.50 \pm 7.77^{\mathrm{a}}$ & $1776.75 \pm 2.99$ & $0.6558 \pm 0.06^{\mathrm{ab}}$ \\
US812 & $46.13 \pm 4.94^{\mathrm{bcd}}$ & $285.50 \pm 8.19^{\mathrm{c}}$ & $1763.50 \pm 5.20$ & $0.6146 \pm 0.08^{\mathrm{b}}$ \\
Volkameriana & $49.05 \pm 3.13^{\mathrm{ab}}$ & $372.50 \pm 4.84^{\mathrm{b}}$ & $1775.25 \pm 7.32$ & $0.6765 \pm 0.06^{\mathrm{ab}}$ \\
X639 & $46.55 \pm 204^{\mathrm{bc}}$ & $364.50 \pm 7.75^{\mathrm{b}}$ & $1788.25 \pm 9.64$ & $0.6414 \pm 0.01^{\mathrm{b}}$ \\
\hline Prob>F & 0.0196 & $<.0001$ & 0.0804 & 0.0378 \\
LSD\%5 & 5.649 & 21.556 & - & 0.0679 \\
\hline
\end{tabular}

${ }^{1}$ For each variable, one-way analysis of variance was performed with rootstocks as the independent variable. Values in rows followed by the different letters are statistically different at $\mathrm{P}<0.05$ (LSD test).

\section{Gas exchange measurements}

Leaf gas exchange measurements showed that rootstock effect was significant on photosynthetic variables of the lemon variety evaluated in the present study. The results of an ANOVA indicated a significant effect $(P \leq 0.01)$ on the net photosynthetic rate $\left(P_{\mathrm{N}}\right)$ of Interdonato leaves (Fig. $\left.1 \mathrm{~A}\right)$. The highest $P_{\mathrm{N}}$ was recorded on the leaves of young Interdonato trees grafted on to Alemow $\left(8.35 \mu \mathrm{mol} \mathrm{m}^{-2} \mathrm{~s}^{-1}\right)$, sour

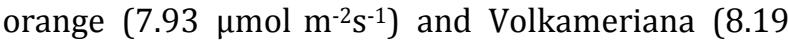
$\mu \mathrm{mol} \mathrm{m} \mathrm{m}^{-2} \mathrm{~s}^{-1}$ ). Leaf $P_{\mathrm{N}}$ was considerably repressed on Carpenter $\left(5.20 \mu \mathrm{mol} \mathrm{m}^{-2} \mathrm{~s}^{-1}\right)$, Carrizo $(4.86 \mu \mathrm{mol} \mathrm{m}$ $\left.{ }^{2} \mathrm{~s}^{-1}\right)$, and Furr $\left(4.93 \mu \mathrm{mol} \mathrm{m}^{-2} \mathrm{~s}^{-1}\right)$. $P_{\mathrm{N}}$ were recorded similar in the leaves of shoots on Bitters $(6.71 \mu \mathrm{mol}$ $\left.\mathrm{m}^{-2} \mathrm{~s}^{-1}\right)$, US812 (6.60 $\left.\mu \mathrm{mol} \mathrm{m} \mathrm{m}^{-2} \mathrm{~s}^{-1}\right)$ and X639 (6.43 $\mu \mathrm{mol} \mathrm{m} \mathrm{m}^{-2} \mathrm{~s}^{-1}$. The inhibition of $P_{\mathrm{N}}$ of the leaves on Carrizo citrange was found to be corresponding with the leaf $\mathrm{Chl}$ concentration and $F v^{\prime} / F m^{\prime}$ of the leaves on same rootstock. A one-way ANOVA indicated that rootstock had also significant effects $(P \leq 0.01)$ on leaf transpiration rate $(E)$ of Interdonato lemon variety (Fig. 1B). Leaves on Alemow, sour orange, and Volkameriana had the highest $E$ similarly with $P_{\mathrm{N}}$ values whereas $E$ value of the leaves on the rest of the rootstock was statistically in the same sub-group according to a LSD test. Similary, significant rootstock effect $(P \leq 0.05)$ on leaf stomatal conductance $\left(g_{\mathrm{S}}\right)$ was determined. The highest $g_{\mathrm{s}}$ was $57.50 \mathrm{mmol} \mathrm{m}^{-2} \mathrm{~s}^{-1}$ in the leaves of shoots grafted on to Volkameriana followed by Alemow (56.25 $\left.\mathrm{mmol} \mathrm{m} \mathrm{m}^{-2} \mathrm{~s}^{-1}\right)$, sour orange $\left(51.25 \mathrm{mmol} \mathrm{m}^{-2} \mathrm{~s}^{-1}\right)$ and X639 (51.20 $\mathrm{mmol} \mathrm{m}^{-2} \mathrm{~s}^{-1}$ ), respectively (Fig. 1C). The lowest $g_{\mathrm{S}}$ was recorded in the leaves of shoots on Carpenter $\left(30.48 \mathrm{mmol} \mathrm{m}^{-2} \mathrm{~s}^{-1}\right)$. Leaf water use efficiency (WUE) slightly varied without significant differences and WUE ranged between 3.04 and 4.15 (Fig 1D). Significant rootstock effect $(P \leq 0.01)$ on the leaf intercellular $\mathrm{CO}_{2}$ concentration of Interdonato variety was determined. Despite decline in $g_{\mathrm{s}}$, the leaves of shoots grafted on to Carpenter and Carrizo citrange had higher $C_{\mathrm{i}}$ values than other rootstocks (Fig. 1E). The $C_{\mathrm{i}}$ was the lowest in the leaves of young trees grafted on Alemow. Similarly, significant increases $(P \leq 0.01)$ in stomatal resistance were determined in the leaves of shoot grafted on Carpenter, followed by Carrizo citrange grown in calcareous soil (Fig 1F). Physiological parameters like measurements of $\mathrm{CO}_{2}$-gas exchange can confirm plant tolerance to fe deficiency or high $\mathrm{pH}$ conditions. (Morales et al., 2000; Chouliaras et al., 2005; Bavaresco et al., 2006; Molassiotis et al., 2006; Larbi et al., 2006). Research has showen that the 
presence of lime in calcareous soils induced iron deficiency resulting in a reduction in net photosynthetic rate of the leaves (Morales et al., 1994; Larbi et al., 2006; Nenova, 2008). GonzálesMas et al. (2009) indicated that $P_{\mathrm{N}}$ of the leaves of Navelina orange variety leaf on Carrizo was the lowest and different rootstocks significantly affected the $P_{\mathrm{N}}$ of Navelina variety growing in calcareous soils. The lime-induced iron deficiency has been reported to reduce $\mathrm{Chl}$ and $P_{\mathrm{N}}$ levels in citrus leaves (Hamzé et al., 1986; Byrne et al., 1995; Cimen et al., 2014; Incesu et al., 2015). In addition, Fe deficiency has discernible impact on the stomatal conduction of plants since of taking a part in numerous enzyme systems and for energy exchange during photosynthesis. On the other side, leaf water potential straightforwardly directs leaf transpiration, gas trade, and stomatal conduction in trees developed in calcareous soils enduring from $\mathrm{Fe}$ insufficiency (Sperry, 2000; Meinzer, 2002; Brodribb and Holbrook, 2003; Eichert et al., 2010). (Ahmadi and Siosemardeh, 2005).

\section{Correlation coefficients analysis}

In the present study, significant correlations were found among the evaluated variables (Table 3 ). The correlation coefficients between stock diameter and scion diameter (0.89); Chl concentration and $P_{\mathrm{N}}$ (0.82); $g_{\mathrm{S}}$ and $P_{\mathrm{N}}(0.78)$ were very significant. Regarding significant correlations, regression analyses were performed and strong relationships were obtained regarding high $r^{2}$ values (Fig. 2). The regression analysis confirmed that $P_{\mathrm{N}}$ was increased by the high $\mathrm{Chl}$ concentrations in the leaves (Figure 2A).
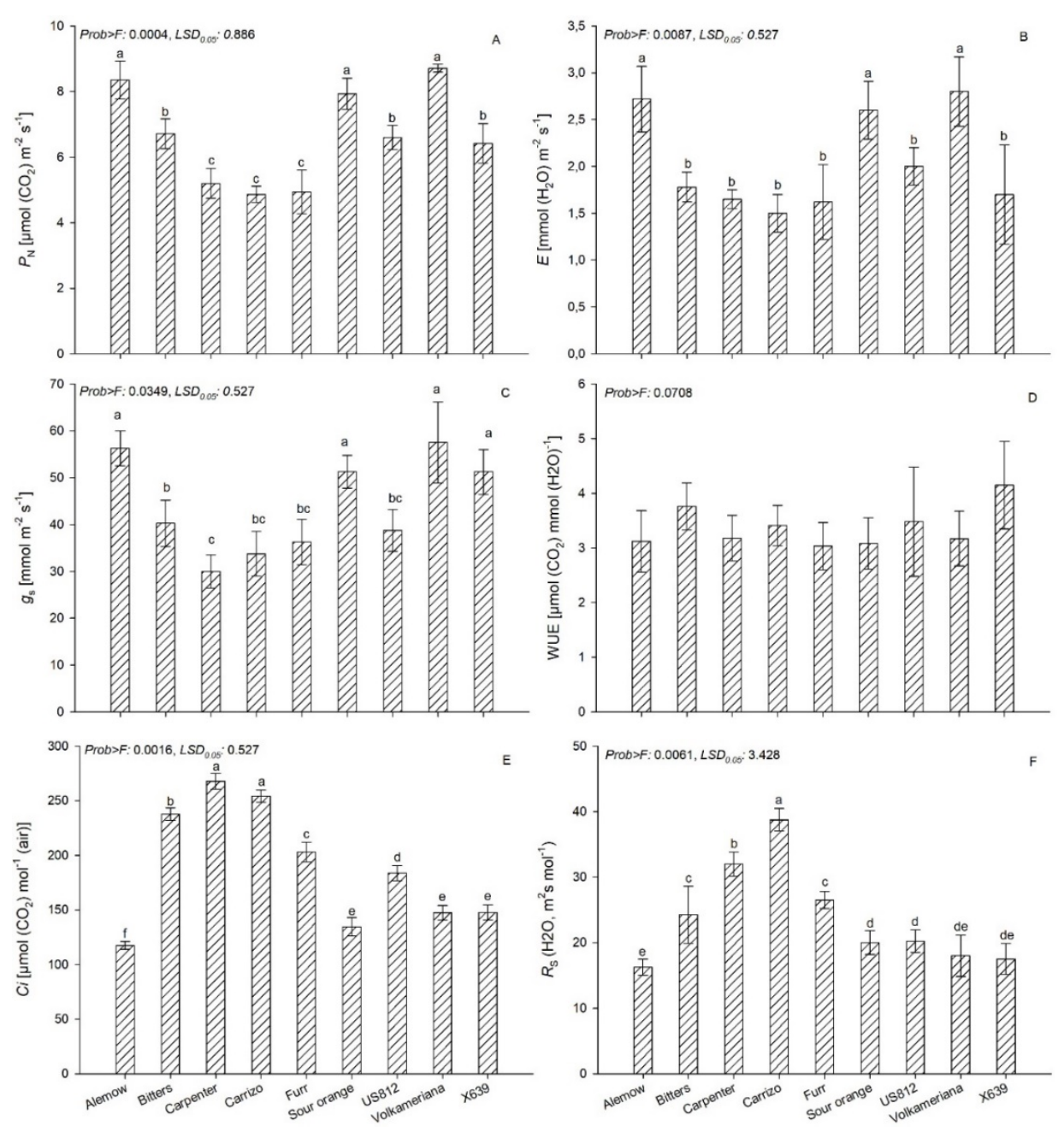

Figure 1. Net photosynthetic rate, $\mathrm{PN}\left[\mu \mathrm{mol}\left(\mathrm{CO}_{2}\right) \mathrm{m}^{-2} \mathrm{~s}^{-1}\right](\mathrm{A})$; transpiration rate, $\mathrm{E}\left(\mathrm{mmol} \mathrm{m}^{-2} \mathrm{~s}^{-1}\right)$ (B); stomatal conductance, $\mathrm{gS}\left(\mathrm{mmol} \mathrm{m}^{-2} \mathrm{~s}^{-1}\right)$ (C); water use efficiency (D); intercellular $\mathrm{CO}_{2}$ concentration (E) and stomatal resistance $\left(\mathrm{m}^{2} \mathrm{~s} \mathrm{~mol}-1\right)(\mathrm{F})$ of Interdonato lemon trees grafted on different rootstocks. 
Table 3. Correlation coefficients analysis between investigated variables

\begin{tabular}{|c|c|c|c|c|c|c|c|c|c|c|c|c|c|}
\hline Variable & $\mathrm{RD}$ & SD & $\mathrm{SD} / \mathrm{SR}$ & Chl & Fo & $\mathrm{Fv}$ & PSII & $\mathrm{P}_{\mathrm{N}}$ & $E$ & WUE & $\mathrm{gs}_{\mathrm{S}}$ & $\mathrm{R}_{\mathrm{S}}$ & $\mathrm{C}_{\mathrm{I}}$ \\
\hline RD & 1.00 & $0.89^{* *}$ & 0.38 & $0.55^{*}$ & $0.67^{* *}$ & $0.55^{*}$ & 0.17 & $0.72^{* *}$ & $0.66^{* *}$ & -0.15 & $0.72^{* *}$ & -0.43 & $-0.58^{*}$ \\
\hline SD & & 1.00 & $0.52^{*}$ & $0.58^{*}$ & $0.61^{* *}$ & $0.58^{*}$ & 0.18 & $0.76^{* *}$ & $0.70^{* *}$ & -0.14 & $0.74^{* *}$ & -0.46 & $-0.62^{* *}$ \\
\hline $\mathrm{SD} / \mathrm{RD}$ & & & 1.00 & 0.46 & 0.49 & 0.43 & 0.10 & $0.56^{*}$ & 0.46 & 0.01 & 0.45 & -0.38 & $-0.53^{*}$ \\
\hline Chl & & & & 1.00 & $0.67^{* *}$ & $0.58^{*}$ & 0.19 & $0.82^{* *}$ & $0.62^{* *}$ & 0.02 & $0.69^{* *}$ & -0.32 & $-0.65^{* *}$ \\
\hline Fo & & & & & 1.00 & $0.89^{* *}$ & 0.15 & $0.75^{* *}$ & $0.66^{* *}$ & -0.08 & $0.69^{* *}$ & -0.36 & $-0.57^{*}$ \\
\hline Fv & & & & & & 1.00 & 0.13 & $0.70^{* *}$ & $0.59^{*}$ & 0.02 & $0.73^{* *}$ & $-0.52^{* *}$ & -0.37 \\
\hline PSII & & & & & & & 1.00 & 0.26 & 0.40 & -0.30 & 0.14 & -0.05 & -0.13 \\
\hline $\mathrm{P}_{\mathrm{N}}$ & & & & & & & & 1.00 & $0.77^{* *}$ & 0.02 & $0.78^{* *}$ & -0.45 & $-0.66^{* *}$ \\
\hline $\mathrm{E}$ & & & & & & & & & 1.00 & $-0.59^{*}$ & $0.60^{*}$ & -0.42 & $-0.65^{* *}$ \\
\hline WUE & & & & & & & & & & 1.00 & 0.04 & 0.03 & 0.05 \\
\hline $\mathrm{g}_{\mathrm{s}}$ & & & & & & & & & & & 1.00 & $-0.60^{*}$ & $-0.72^{* *}$ \\
\hline $\mathrm{R}_{\mathrm{S}}$ & & & & & & & & & & & & 1.00 & $0.73^{* *}$ \\
\hline $\mathrm{C}_{\mathrm{I}}$ & & & & & & & & & & & & & 1.00 \\
\hline Mean & 27.65 & 25.49 & 0.92 & 46.53 & 314.47 & 1754 & 0.64 & 6.63 & 2.04 & 3.36 & 43.92 & 23.50 & 188.18 \\
\hline Std & 6.27 & 6.32 & 0.04 & 3.51 & 63.32 & 29.71 & 0.18 & 1.47 & 0.59 & 0.70 & 10.85 & 7.15 & 53.34 \\
\hline $\mathrm{n}$ & 54 & 54 & 54 & 54 & 54 & 54 & 54 & 54 & 54 & 54 & 54 & 54 & 54 \\
\hline
\end{tabular}

$1 * *-\mathrm{p} \leq 0.01, *-\mathrm{p} \leq 0.05 . \mathrm{RD}=$ rootstock diameter, $\mathrm{SD}=$ scion diameter.

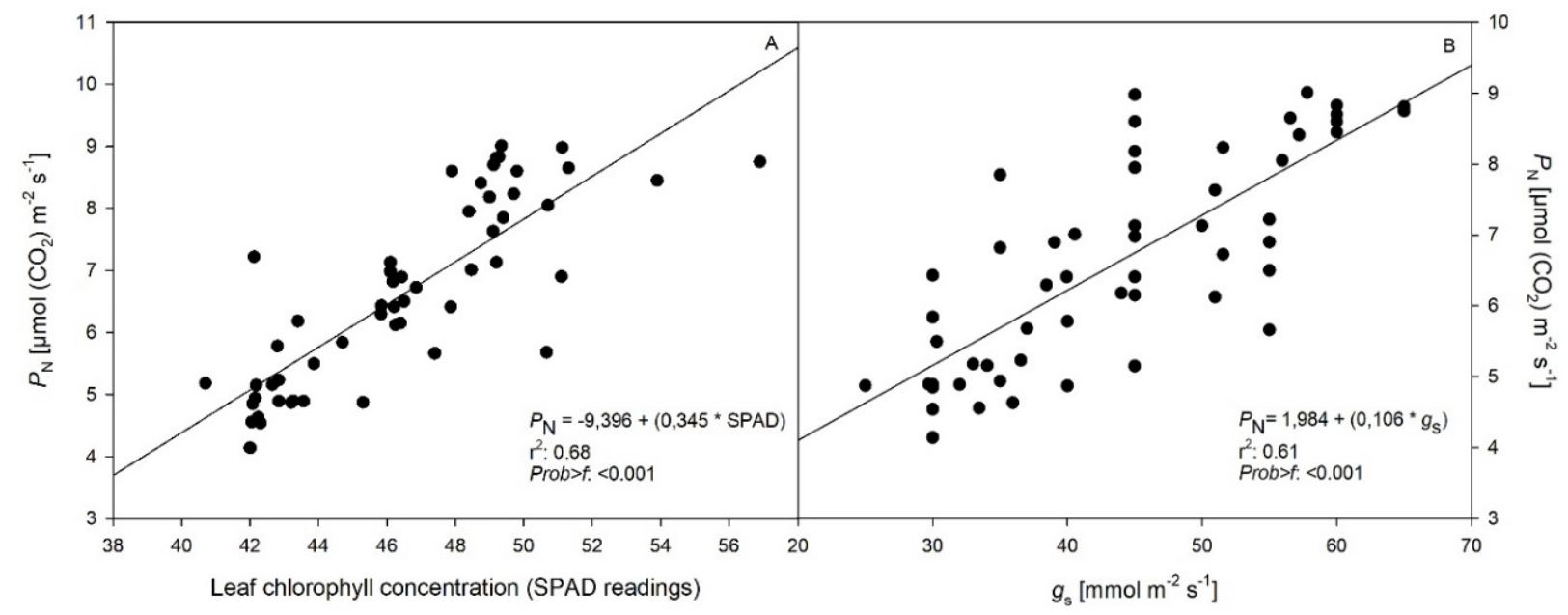

Figure 2. Regressions SPAD readings vs $P_{\mathrm{N}}(\mathrm{A})$ and $g_{\mathrm{s}}$ vs $P_{\mathrm{N}}(\mathrm{B})$.

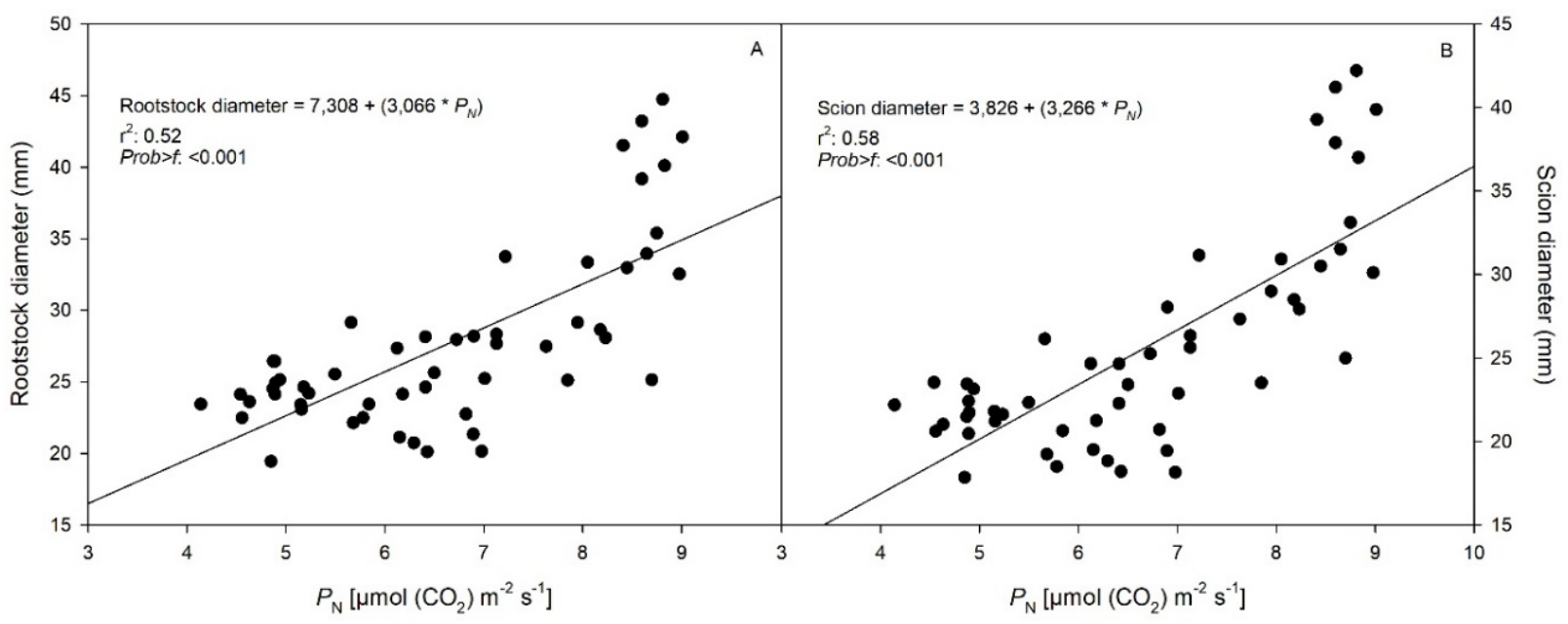

Figure 3. Regressions between $\mathrm{A}=P_{\mathrm{N}}$ vs rootstock diameter and $\mathrm{B}=P_{\mathrm{N}}$ vs scion dimeter. 
The relationship between $g_{\mathrm{s}}$ and $P_{\mathrm{N}}$ was also strong and the present study confirmed that the opening of $g_{\mathrm{S}}$ in the leaves significantly affected $P_{\mathrm{N}}$ (Figure 2B). In addition, high $r^{2}$ values marked that plant growth (scion and stock diameter) was significantly related to $P_{\mathrm{N}}$. Two regression analysis showed that rootstock diameter (Fig 3A) and scion diameter (Fig 3B) were increased by the increasing rate of photosynthesis.

\section{Conclusions}

The present study assessed the effects of rootstock on scion growth and photosynthesis of Interdonato lemon which is an important economic variety in Turkey's lemon production. Scion growth was remarkably affected by the usage of different rootstocks. Young Interdonato lemon trees grafted on 'Alemow', 'Volkameriana' and sour orange performed much better on calcareous soil. Since the Mediterranean region of Turkey has calcareous soils, concentration of leaf $\mathrm{Chl}$ in lemon trees grafted on Carrizo and Furr were substantially reduced. Young Interdonato trees grafted on Alemow', 'Volkameriana' and sour orange had better early plant development results and vigorous growth than the other investigated rootstocks in this experiment. Thus, using these rootstocks for lemon production in the areas without frost risk should be beneficial. However, compatibility between rootstocks and scion should be further observed, especially for trifoliate hybrid rootstocks/lemon combinations, and this will take more time.

\section{Acknowledgements}

The author is grateful that the manuscript has been read and corrected critically by Dr. Ben FABER. In addition, the author would like to thank to Ridvan ATUK (MSc) and 'Atlas Tarım' for supplying plant materials.

\section{References}

Ahmadi, A., Siosemardeh, A. 2005. Investigation on the Physiological Basis of Grain Yield and Drought Resistance in Wheat: Leaf Photosynthetic Rate, Stomatal Conductance, and Non-stomatal Limitations. 7 (5): 5.

Bassal, M.A. 2009. Growth, yield and fruit quality of 'Marisol' clementine grown on four rootstocks in Egypt. Scientia Horticulturae 119 (2): 132-137.

Bavaresco, L., Bertamini, M., Iacono, F. 2006. Lime-induced chlorosis and physiological responses in grapevine (Vitis vinifera L. cv. Pinot blanc) leaves. Vitis Geilweilerhof 45 (1): 45-46.
Bisio, L., Vignale, B., Carrau, F., Diez JC. 2003. Evaluation of nine rootstocks for 'Owari' Satsuma mandarin in Uruguay. Proc Int Soc Citriculture, IX Congress 1: 479-481.

Bowman, K.D., Rouse, R.E. 2006. US-812 Citrus Rootstock. HortScience 41 (3): 832-836.

Brodribb, T.J., Holbrook, N.M. 2003. Stomatal Closure during Leaf Dehydration, Correlation with Other Leaf Physiological Traits. Plant Physiology 132 (4): 2166-2173.

Byrne, D.H. (Texas A.U., Rouse, R.E., Sudahono. 1995. Tolerance of citrus rootstocks to lime-induced iron chlorosis. Subtropical plant science : journal of the Rio Grande Valley Horticultural Society (USA).

Castle, W.S., Nunnallee, J., Manthey, J.A. 2009. Screening Citrus Rootstocks and Related Selections in Soil and Solution Culture for Tolerance to Low-iron Stress. HortScience 44 (3): 638-645.

Chouliaras, V., Therios, I., Molassiotis, A., Patakas, A., Diamantidis, G. 2005. Effect of Iron Deficiency on Gas Exchange and Catalase and Peroxidase Activity in Citrus. Journal of Plant Nutrition 27 (12): 20852099.

Cimen, B., Yesiloglu, T. 2016. Rootstock Breeding for Abiotic Stress Tolerance in Citrus. Abiotic and Biotic Stress in Plants - Recent Advances and Future Perspectives.

Cimen, B., Yesiloglu, T., Incesu, M., Yilmaz, B. 2014. Growth and photosynthetic response of young 'Navelina' trees budded on to eight citrus rootstocks in response to iron deficiency. New Zealand Journal of Crop and Horticultural Science 42 (3): 170-182.

Eichert, T., Peguero-Pina, J.J., Gil-Pelegrín, E., Heredia, A., Fernández, V. 2010. Effects of iron chlorosis and iron resupply on leaf xylem architecture, water relations, gas exchange and stomatal performance of field-grown peach (Prunus persica). Physiologia Plantarum 138 (1): 48-59.

FAO. 2019. 'FAOSTAT' FAO agricultural statistics. Online at http://www.fao.org/faostat/en (accessed 8 April 2019).

Federici, C.T., Kupper, R.S., Roose, M.L. 2009. “'Bitters”, "Carpenter" and "Furr" Trifoliate Hybrids: Three New Citrus Rootstocks' Online at https://plantbiology.ucr.edu/faculty/new\%20citru s\%20rootstocks\%202009.pdf.

Fernández, V., Del Río, V., Abadía, J., Abadía, A. 2006. Foliar Iron Fertilization of Peach (Prunus persica (L.) Batsch): Effects of Iron Compounds, Surfactants and Other Adjuvants. Plant and Soil 289 (1): 239252 . 
Forner-Giner, M.A., Alcaide, A., Primo-Millo, E., Forner, J.B. 2003. Performance of 'Navelina' orange on 14 rootstocks in Northern Valencia (Spain). Scientia Horticulturae 98 (3): 223-232.

González-Mas, M.C., Llosa, M.J., Quijano, A., Forner-Giner, M.A. 2009. Rootstock Effects on Leaf Photosynthesis in 'Navelina' Trees Grown in Calcareous Soil. HortScience 44 (2): 280-283.

González-Vallejo, E.B., Morales, F., Cistué, L., Abadía, A., Abadía, J. 2000. Iron Deficiency Decreases the Fe(III)-Chelate Reducing Activity of Leaf Protoplasts. Plant Physiology 122 (2): 337-344.

Hamzé, M., Ryan, J., Zaabout, M. 1986. Screening of citrus rootstocks for lime-induced chlorosis tolerance. Journal of Plant Nutrition 9 (3-7): 459-469.

Incesu, M., Cimen, B., Yesiloglu, T., Yilmaz, B. 2015. Effects of Some Rootstocks on Photosynthetic Performance Of Young 'Valencia' Orange Trees In Calcareous Soil. 6.

Jifon, J.L., Syvertsen, J.P., Whaley, E. 2005. Growth Environment and Leaf Anatomy Affect Nondestructive Estimates of Chlorophyll and Nitrogen in Citrus sp. Leaves. Journal of the American Society for Horticultural Science 130 (2): 152-158.

Larbi, A., Abadía, A., Abadía, J., Morales, F. 2006. Down coregulation of light absorption, photochemistry, and carboxylation in Fe-deficient plants growing in different environments. Photosynthesis Research 89 (2): 113-126.

Lawlor, D.W. 1995. 'The effects of water deficit on photosynthesis In: Environment and plant metabolisim (Smirnoff ed.)'ResearchGate. Online at https://www.researchgate.net/publication/28415 0725_The_effects_of_water_deficit_on_photosynthe sis_In_Environment_and_plant_metabolisim_Smirn off_ed (accessed 19 April 2019).

Legua, P., Bellver, R., Forner, J., Forner-Giner, M.A. 2011 Plant growth, yield and fruit quality of 'Lane Late' navel orange on four citrus rootstocks. Spanish Journal of Agricultural Research 9 (1): 271-279.

López-Millán, A.F., Morales, F., Andaluz, S., Gogorcena, Y., Abadía, A., Rivas, J.D.L., Abadía, J. 2000. Responses of Sugar Beet Roots to Iron Deficiency. Changes in Carbon Assimilation and Oxygen Use. Plant Physiology 124 (2): 885-898.

Meinzer, F.C. 2002. Co-ordination of vapour and liquid phase water transport properties in plants. Plant, Cell \& Environment 25 (2): 265-274.
Molassiotis, A., Tanou, G., Diamantidis, G., Patakas, A., Therios, I. 2006. Effects of 4-month Fe deficiency exposure on $\mathrm{Fe}$ reduction mechanism, photosynthetic gas exchange, chlorophyll fluorescence and antioxidant defense in two peach rootstocks differing in $\mathrm{Fe}$ deficiency tolerance. Journal of Plant Physiology 163 (2): 176-185.

Morales, F., Abadía, A., Belkhodja, R., Abadía, J. 1994. Iron deficiency-induced changes in the photosynthetic pigment composition of field-grown pear (Pyrus communis L) leaves. Plant, Cell \& Environment 17 (10): 1153-1160.

Morales, F., Belkhodja, R., Abadía, A., Abadía, J. 2000. Photosystem II efficiency and mechanisms of energy dissipation in iron-deficient, field-grown pear trees (Pyrus communis L.). Photosynthesis Research 63 (1): 9-21.

Nenova, V.R. 2008. Growth and photosynthesis of pea plants under different iron supply. Acta Physiologiae Plantarum 31 (2): 385.

Pestana, M., Correia, P.J., David, M., Abadía, A., Abadía, J., Varennes, A. de. 2011. Response of five citrus rootstocks to iron deficiency. Journal of Plant Nutrition and Soil Science 174 (5): 837-846.

Pestana, M., Varennes, A. de, Abadía, J., Faria, E.A. 2005. Differential tolerance to iron deficiency of citrus rootstocks grown in nutrient solution. Scientia Horticulturae 104 (1): 25-36.

Ribeiro, R.V., Machado, E.C., Santos, M.G., Oliveira, R.F. 2009. Photosynthesis and water relations of wellwatered orange plants as affected by winter and summer conditions. Photosynthetica 47 (2): 215222.

Salvo, A., Bruno, M., Torre, G.L.L., Vadalà, R., Mottese, A.F., Saija, E., Mangano, V., Casale, K.E., Cicero, N., Dugo, G. 2016. Interdonato lemon from Nizza di Sicilia (Italy): chemical composition of hexane extract of lemon peel and histochemical investigation. Natural Product Research 30 (13): 1517-1525.

Shah, S.T., Rahman, S., Khan, N. 2016. Viability of meyer lemon over sour orange rootstock. Pure and Applied Biology 5 (2): 326-331.

Sperry, J.S. 2000. Hydraulic constraints on plant gas exchange. Agricultural and Forest Meteorology 104 (1): 13-23.

UCR. 2019. Citrus variety 'X639'. Online at https://citrusvariety.ucr.edu/citrus/X639.html (accessed 22 April 2019). 
Yang, C.W., Wang, P., Li, C.Y., Shi, D.C., Wang, D.L. 2008. Comparison of effects of salt and alkali stresses on the growth and photosynthesis of wheat. Photosynthetica 46 (1): 107-114.
Yildirim, B., Ye, T., Çimen, B. 2010. Fruit yield and quality of Santa Teresa lemon on seven rootstocks in Adana (Turkey). African Journal of Agricultural Research 5 (10): 1077-1081. 